\title{
Optimization of N, P, K for soilless production of Cannabis sativa in the flowering stage using response surface analysis
}

\author{
Lewys Bevan ${ }^{1}$, Max Jones ${ }^{2}$, and Youbin Zheng ${ }^{1^{*}}$ \\ ${ }^{1}$ School of Environmental Science, ${ }^{2}$ Department of Plant Agriculture, University of Guelph, \\ Guelph, ON, Canada \\ * Correspondence: \\ yzheng@uoguelph.ca
}

\begin{abstract}
Following legalization, cannabis has quickly become an important horticultural crop in Canada and increasingly so in other parts of the world. However, due to previous legal restrictions on cannabis research there are limited scientific data on the relationship between nitrogen $(\mathrm{N})$, phosphorus (P), and potassium (K) supply (collectively: NPK) and the crop yield and quality. This study examined the response of a high delta-9-tetrahydrocannabinol (THC) Cannabis sativa cultivar grown in deep-water culture with different nutrient solution treatments varying in their concentrations $\left(\mathrm{mg} \mathrm{L}^{-1}\right)$ of $\mathrm{N}(70,120,180,250,290), \mathrm{P}(20,40,60,80,100)$ and $\mathrm{K}(60,120$, $200,280,340$ ) according to a central composite design. Results demonstrated that inflorescence yield responded quadratically to $\mathrm{N}$ and $\mathrm{P}$, with the optimal concentrations predicted to be 194 and $59 \mathrm{mg} \mathrm{L}^{-1}$, respectively. Inflorescence yield did not respond to $\mathrm{K}$ in the tested range. These results can provide guidance to cultivators when formulating nutrient solutions for soilless cannabis production and demonstrates the utility of surface response design for efficient multinutrient optimization.
\end{abstract}

\section{Keywords}

Cannabis, cannabinoids, nutrients, nitrogen $(\mathrm{N})$, phosphorus $(\mathrm{P})$, potassium $(\mathrm{K})$, yield, response surface methodology

\section{Introduction}

Drug-type cannabis (Cannabis sativa) is an important horticultural crop grown for medicinal and recreational purposes. Historically, many countries have prohibited the cultivation of drug-type cannabis which consequently provided a significant barrier into research on this crop. However, change in social attitudes toward consumption of cannabis has led to the repeal of cannabis prohibition in several countries/regions around the world. Following the 2018 repeal of cannabis prohibition in Canada, production of cannabis has quickly become an important part of the Canadian horticulture industry worth billions of dollars annually (Zheng, 2021). However, cannabis cultivators still lack scientific information about optimal growing conditions, such as supply of mineral nutrients, to help maximize crop yields, quality, and profits. 
Proper supply of mineral nutrients is essential for the efficient and sustainable cultivation of any crop. Among the most important mineral nutrients for plants are nitrogen $(\mathrm{N})$, phosphorus $(\mathrm{P})$, and potassium $(\mathrm{K})$. However, few studies have investigated the response of cannabis to these nutrients. As a result, cannabis cultivators currently rely on fertilizer nutrient recipes developed by fertilizer companies, or by community consensus based on previously clandestine production. This poses a problem because deficient or excessive supply of nutrients may reduce yield (Caplan et al., 2017b, 2017a) or lead to environmental pollution from runoff of excess nutrients (Beerling et al., 2014; Zheng, 2018). Nutrient runoff is an issue in many agricultural areas of the world because excess nutrients, specifically $\mathrm{P}$, can lead to the eutrophication of water bodies (Schindler et al., 2016). In Ontario (the Canadian province in which this study was conducted) disposal of waste greenhouse nutrient solution, including from cannabis production facilities, is regulated by law at considerable cost to the cultivators (Ontario Ministry of Agriculture Food and Rural Affairs, 2019). An understanding of cannabis' mineral nutrient requirements can help us better synchronize nutrient supply and demand to maximize production while reducing nutrient waste and resulting environmental impacts.

Recent peer-reviewed studies have started to examine the response of Cannabis to mineral nutrients, but this area of research remains largely unexplored. These studies indicate the optimal $\mathrm{N}$ supply for both vegetative and flowering stages of cannabis production using conventional fertilizers is approximately $160 \mathrm{mg} \mathrm{L}^{-1}$ (Saloner and Bernstein, 2020, 2021). Plants supplied with $\mathrm{N}$ below $160 \mathrm{mg} \mathrm{L}^{-1}$ during the vegetative stage saw reduced photosynthetic capacity and plant growth, and during the flowering stage saw reduced inflorescence yield, though cannabinoid concentrations (not total production) were greater at extremely low $\mathrm{N}$ rates. The optimal $\mathrm{N}$ supply for plants grown with liquid organic fertilizers seems to be higher, with the highest yields being achieved with an organic $\mathrm{N}$ supply of approximately 390 and $260 \mathrm{mg} \mathrm{L}^{-1}$ for the vegetative and flowering stages, respectively (Caplan et al., 2017b, 2017a). Given the limited number of studies and the relative importance of $\mathrm{N}$ on plant growth and development, collecting more information about cannabis response to $\mathrm{N}$ are needed to establish more accurate recommendations.

Phosphorus nutrition has long been a focus in cannabis cultivation. Growers often supply plants with relatively high $\mathrm{P}$ concentrations (up to $200 \mathrm{mg} \mathrm{L}^{-1}$ ) during the flowering stage based on a belief that this promotes flower development. However, there is little evidence to support this practice. A recent study found that cannabis plants in the vegetative stage supplied with $100 \mathrm{mg}$ $\mathrm{L}^{-1} \mathrm{P}$ performed similar to those supplied with $30 \mathrm{mg} \mathrm{L}^{-1} \mathrm{P}$ (Shiponi and Bernstein, 2021). High $\mathrm{P}$ concentration in the nutrient solution creates a situation where environmental pollution from excess $\mathrm{P}$ is more likely. Clearly, the practice of supplying cannabis with very high concentrations of $\mathrm{P}$ needs to be evaluated.

While there are no published studies examining effect of $\mathrm{K}$ on inflorescence quality, some recent studies have looked at how $\mathrm{K}$ impacts inflorescence yield. Yield of aquaponically-grown cannabis (g/plant) increased linearly with increasing nutrient solution $\mathrm{K}$ concentration in the range of 15-150 $\mathrm{mg} \mathrm{L}^{-1}$ (Yep and Zheng, 2020). The nitrogen concentration $\left(75 \mathrm{mg} \mathrm{L}^{-1}\right.$ ) used by Yep and Zheng (2020) reflects that of a typical aquaponic solution, but this $\mathrm{N}$ concentration is fairly low compared to conventional hydroponic nutrient solutions and may have been a limiting factor for plant growth and yield (Yep et al., 2020b). For the vegetative stage, cannabis plants 
supplied with $15 \mathrm{mg} \mathrm{L}^{-1} \mathrm{~K}$ had reduced growth and displayed foliar symptoms characteristic of $\mathrm{K}$ deficiency, while plants that received $60-240 \mathrm{mg} \mathrm{L}^{-1} \mathrm{~K}$ produced substantially more biomass and did not display K deficiency symptoms (Saloner et al., 2019). While there is a lack of recommendation based on scientific research, some fertilizer companies are recommending 300$400 \mathrm{mg} \mathrm{L}^{-1} \mathrm{~K}$. More research is needed to determine the optimal nutrient solution $\mathrm{K}$ concentration during cannabis flowering in soilless production systems when other nutrient elements are not limiting.

A challenge in developing fertilizer recommendations is that the number of combinations of nutrient concentrations that can be empirically tested is limited due to logistical and statistical considerations. As a result, most nutrient studies have a limited range of nutrient compositions that can overlook potential nutrient interactions across a broad range of nutrient compositions. Studies on cannabis response to nutrients so far have either investigated different concentrations of one nutrient while holding the others constant (Saloner et al., 2019; Saloner and Bernstein, 2020, 2021; Shiponi and Bernstein, 2021), or provided different concentrations of NPK in a set ratio (Caplan et al., 2017b, 2017a; Bernstein et al., 2019). Neither of these approaches can evaluate nutrient interactions, which could have substantial impacts on the recommendations of optimum application rates.

Response surface methodology (RSM) is an alternative experimental design capable of concurrently optimizing multiple factors over a wide range of levels using fewer experimental units compared to traditional designs (Myers et al., 2016). The efficiency of this design is achieved through using the fewest number of experimental units which conserves space, time, and resources. Nutrient solution optimization has been approached by some researchers as a 'mixture system' which is a type of multifactor optimization similar to response surface analysis (De Rijck and Schrevens, 1998, 1999a). However, the experimental design of a mixture system only optimizes the nutrient composition of the solution but not the nutrient concentration as the design maintains a constant total concentration of nutrients in the solution. RSM allows the optimization of both the nutrient solution composition and the concentrations of individual components without this limitation. Given the high cost of cannabis and growing space being limited to government-approved production facilities, the reduced number of experimental units required for a RSM approach is an advantage over conventional experimental designs.

The objective of this study was to determine the optimal concentrations of NPK for the flowering stage of cannabis in a soilless production system using the RSM approach.

\section{Materials and methods}

\section{Plant material and growing conditions}

The experiment was conducted in a controlled-environment growth room at a Health Canada approved cannabis production facility located in Southern Ontario. A clonal selection of a high delta-9-tetrahydrocannabinol (THC), low cannabidiol (CBD) Cannabis sativa cultivar 'Gelato' was used for this trial. Plants were grown in deep-water culture (DWC) systems. Each DWC unit used a $19 \mathrm{~L}$ white plastic bucket $(36 \mathrm{~cm}$ height $\mathrm{x} 30.5 \mathrm{~cm}$ top outside diameter $\mathrm{x} 26.4 \mathrm{~cm}$ bottom outside diameter) as the nutrient solution reservoir. DWC units were placed on the floor in five 
double rows of ten DWCs each (i.e., 100 DWCs total), each with one plant, spaced ten cm between adjacent units, $15 \mathrm{~cm}$ within the rows, and a one metre aisle-space between rows (Figure 1). Uniform two-week-old cuttings ( $\sim 15 \mathrm{~cm}$ tall, $5-6$ nodes trimmed to $3-4$ leaves) rooted in rockwool cubes were transplanted into each DWC unit using a mesh pot (FHD Plastics, 0.62 $\mathrm{L}, 10.3 \mathrm{~cm}$ height $\times 12.5 \mathrm{~cm}$ diameter) filled with $8-16 \mathrm{~mm}$ expanded clay pebbles (Liapor, Hallerndorf, Germany) and inserted flush to the top of the bucket lids, with the bottom three $\mathrm{cm}$ of the mesh pot submerged in the nutrient solution. Each DWC bucket was supplied with nutrient solution and had an air-stone (Pawfly ASC030, $30 \mathrm{~mm}$ height x $18 \mathrm{~mm}$ diameter) providing 1.5 litres of air per minute to continuously mix and aerate the solution. The nutrient solutions in all DWC units were drained and replaced with $17 \mathrm{~L}$ of fresh nutrient solution weekly. The initial $\mathrm{pH}$ of the nutrient solutions was adjusted to 5.6 with $1 \mathrm{M}$ sulphuric acid or $1 \mathrm{M}$ sodium hydroxide, as needed. DWC units were topped up with $\mathrm{pH}$-adjusted (5.6) rainwater three to four days after each weekly nutrient solution replacement to replace water lost due to evapotranspiration.

Nutrient solution $\mathrm{pH}$ and electrical conductivity $(\mathrm{EC}, \mathrm{mS} \mathrm{cm}-1)$ were measured using a hand-held meter (BLU2300E Combo Meter, Bluelab Corporation, New Zealand). EC and pH of treatment feed solution and of the final leachate are listed in Table 1.

Table 1. Electrical conductivity (EC) and pH offeed and leachate nutrient solutions.

\begin{tabular}{ccccc}
\hline Treatment & $\begin{array}{c}\text { Feed EC } \\
\left(\mathrm{mS} \mathrm{cm}^{-1}\right)\end{array}$ & $\begin{array}{c}\text { Drain EC } \\
\left(\mathrm{mS} \mathrm{cm}^{-1}\right)\end{array}$ & Feed $\mathrm{pH}$ & Drain $\mathrm{pH}$ \\
\hline 1 & 1.5 & 1.1 & 5.6 & 6.5 \\
2 & 2.4 & 2.3 & 5.6 & 5.6 \\
3 & 1.5 & 1.2 & 5.6 & 6.2 \\
4 & 2.5 & 2.2 & 5.6 & 5.6 \\
5 & 2.1 & 2.0 & 5.6 & 6.5 \\
6 & 2.5 & 2.5 & 5.6 & 5.9 \\
7 & 2.1 & 1.9 & 5.6 & 6.2 \\
8 & 2.5 & 2.2 & 5.6 & 6.1 \\
9 & 1.8 & 1.8 & 5.6 & 6.5 \\
10 & 2.8 & 2.8 & 5.6 & 5.6 \\
11 & 2.0 & 1.9 & 5.6 & 6.6 \\
12 & 2.1 & 2.0 & 5.6 & 5.6 \\
13 & 1.8 & 1.6 & 5.6 & 5.3 \\
14 & 2.3 & 2.4 & 5.6 & 6.4 \\
15 & 1.9 & 1.9 & 5.6 & 5.9 \\
16 & 1.9 & 1.8 & 5.6 & 6.0 \\
17 & 1.9 & 1.8 & 5.6 & 5.6 \\
18 & 1.9 & 1.8 & 5.6 & 6.1 \\
19 & 1.9 & 1.8 & 5.6 & 5.9 \\
20 & 1.9 & 1.9 & 5.6 & 5.9 \\
\hline
\end{tabular}


Figure 1. Rows of deep-water culture units containing trial plants at the end of the three-week vegetative stage.

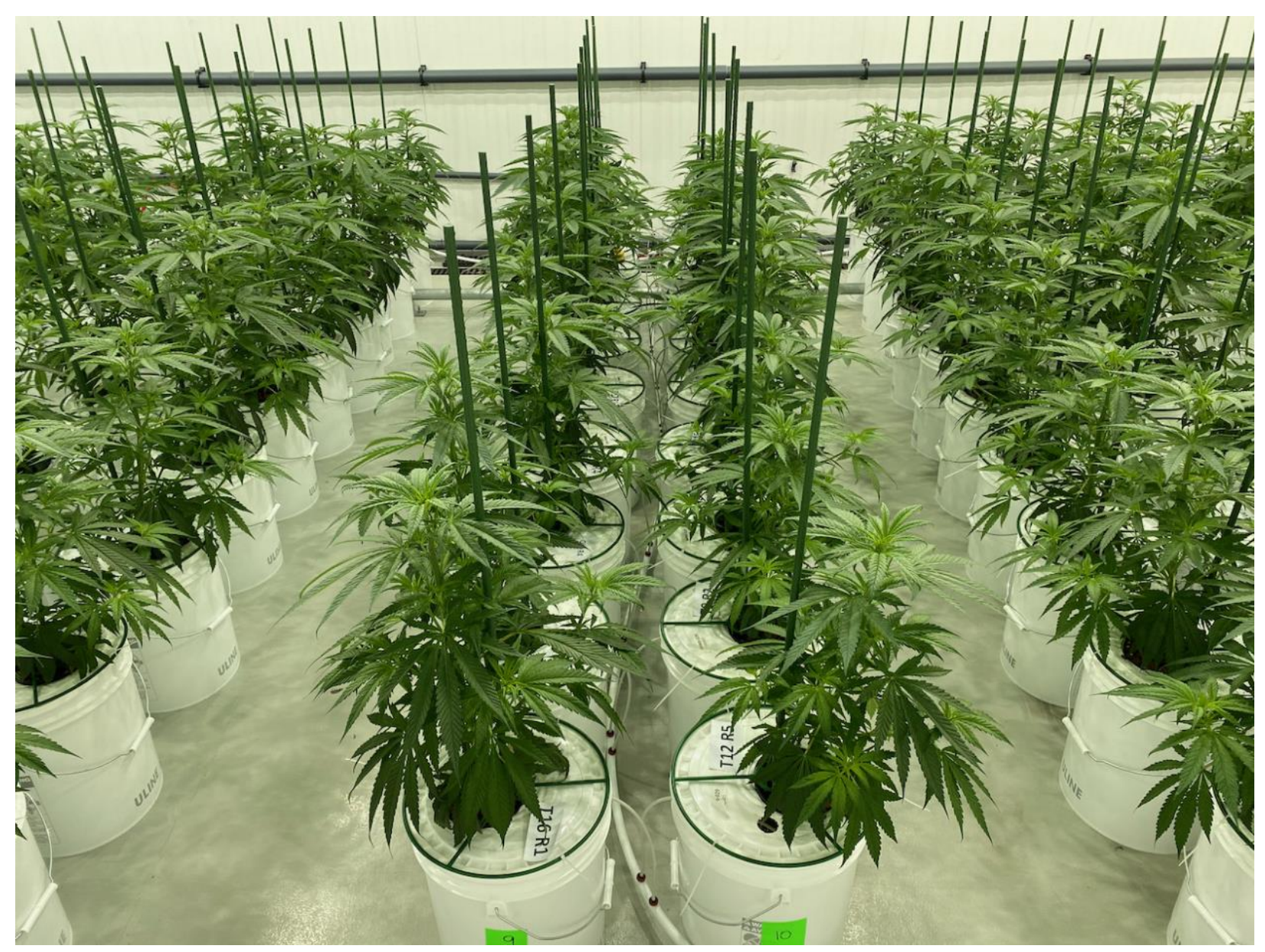

Plants were grown in the DWC systems vegetatively, under 18/6-h light/dark conditions, for three weeks before switching to a 12/12-h light/dark (i.e., short-day) photoperiod, to induce flowering. Plants were grown under short-day conditions for seven weeks before being harvested. Light was provided by $1000 \mathrm{~W}$ metal halide bulbs at an average canopy-level photosynthetically photon flux density of $570 \mu \mathrm{mol} \mathrm{m} \mathrm{m}^{-2} \mathrm{~s}^{-1}$. The air temperature and relative humidity were set at $25{ }^{\circ} \mathrm{C}$ and $65 \%$, respectively. There was no $\mathrm{CO}_{2}$ supplementation.

\section{Experimental design and treatments}

A three-factor (i.e., N, P, and K), second order central rotatable composite design was used to model cannabis responses to these mineral nutrients. Following a response surface design, treatments combinations were defined by their concentrations of $\mathrm{N}(70,120,180,250$, and 290 $\left.\mathrm{mg} \mathrm{L}^{-1}\right), \mathrm{P}\left(20,40,60,80\right.$, and $\left.100 \mathrm{mg} \mathrm{L}^{-1}\right)$, and $\mathrm{K}$ (60, 120, 200, 280, and $340 \mathrm{mg} \mathrm{L}^{-1}$ ) (Table 2). The experimental unit was one plant grown in its individual DWC unit. There were five replicates per treatment. Plants were randomly assigned to each nutrient solution treatment by generating a random sequence of numbers from 1 to 100 arranged in ten columns and ten rows (matching DWC unit arrangement). For the first three weeks following transplant, all plants 
received the same nutrient solution containing $\left(\mathrm{mg} \mathrm{L}^{-1}\right)$ : $112.8 \mathrm{~N}-N O_{3}, 7.2 \mathrm{~N}^{-N_{4}}, 40 \mathrm{P}, 180 \mathrm{~K}$, $110 \mathrm{Ca}, 45 \mathrm{Mg}$, and $60 \mathrm{~S}$. Once switched to short-day conditions, plants received their respective treatment nutrient solutions for the remainder of the experiment. The major cation and anion compositions of the treatment nutrient solutions are detailed in Table 3. All treatments were formulated to have the same $\mathrm{N}-\mathrm{NH}_{4} / \mathrm{N}-\mathrm{NO}_{3}$ ratio (1:16). All plants received the same concentration of a commercial ethylenediaminetetraacetate (EDTA) and diethylenetriamine pentaacetate (DTPA) chelated micronutrient mix throughout both vegetative and flowering stages (Plant-Prod Chelated Micronutrient Mix; Master Plant-Prod Inc., Brampton, Ontario, Canada) containing $\left(\mathrm{mg} \mathrm{L}^{-1}\right): 2.1 \mathrm{Fe}, 0.6 \mathrm{Mn}, 0.12 \mathrm{Zn}, 0.03 \mathrm{Cu}, 0.39 \mathrm{~B}$, and 0.018 Mo.

Table 2. Range and levels of the experimental factors according to three-factor central rotatable composite design.

\begin{tabular}{cccccc}
\hline & \multicolumn{5}{c}{ Range and levels } \\
\cline { 2 - 6 } Element & $-1.68^{\mathrm{b}}$ & -1 & 0 & 1 & $1.68^{\mathrm{b}}$ \\
\hline $\mathrm{N}^{\mathrm{a}}$ & 70 & 120 & 180 & 250 & 290 \\
$\mathrm{P}$ & 20 & 40 & 60 & 80 & 100 \\
$\mathrm{~K}$ & 60 & 120 & 200 & 280 & 340 \\
\hline${ }^{a} \mathrm{~N}-\mathrm{NH}_{4}+\mathrm{N}-\mathrm{NO}_{3}$ \\
${ }^{b}$ Radius adjustment factor for a three-factor design to make the design rotatable
\end{tabular}

Table 3. Composition of major anions and cations in the treatment nutrient solutions.

\begin{tabular}{cccccccc}
\hline & \multicolumn{6}{c}{ Nutrient concentrations $\left(\mathrm{mg} \mathrm{L}^{-1}\right)$} \\
\cline { 2 - 7 } Treatment & $\mathrm{N}$ & $\mathrm{P}$ & $\mathrm{K}$ & $\mathrm{Ca}$ & $\mathrm{Mg}$ & $\mathrm{S}^{\mathrm{a}}$ & $\mathrm{Cl}$ \\
\hline 1 & 120 & 40 & 120 & 130 & 45 & 180 & 5.0 \\
2 & 250 & 40 & 120 & 260 & 45 & 180 & 5.0 \\
3 & 120 & 80 & 120 & 130 & 45 & 180 & 5.0 \\
4 & 250 & 80 & 120 & 260 & 45 & 180 & 5.0 \\
5 & 120 & 40 & 280 & 130 & 45 & 180 & 190 \\
6 & 250 & 40 & 280 & 190 & 45 & 180 & 5.0 \\
7 & 120 & 80 & 280 & 130 & 45 & 180 & 120 \\
8 & 250 & 80 & 280 & 190 & 45 & 180 & 5.0 \\
9 & 70 & 60 & 200 & 130 & 45 & 180 & 190 \\
10 & 290 & 60 & 200 & 260 & 45 & 180 & 5.0 \\
11 & 180 & 20 & 200 & 130 & 45 & 180 & 20 \\
12 & 180 & 100 & 200 & 160 & 45 & 180 & 5.0 \\
13 & 180 & 60 & 60 & 190 & 45 & 180 & 5.0 \\
14 & 180 & 60 & 340 & 130 & 45 & 180 & 95 \\
15 & 180 & 60 & 200 & 130 & 45 & 180 & 5.0 \\
16 & 180 & 60 & 200 & 130 & 45 & 180 & 5.0 \\
17 & 180 & 60 & 200 & 130 & 45 & 180 & 5.0 \\
18 & 180 & 60 & 200 & 130 & 45 & 180 & 5.0 \\
19 & 180 & 60 & 200 & 130 & 45 & 180 & 5.0 \\
20 & 180 & 60 & 200 & 130 & 45 & 180 & 5.0 \\
\hline
\end{tabular}

${ }^{a}$ Includes sulphur added by the sulphuric acid used to adjust pH of the nutrient solution. 


\section{Plant measurements}

\section{Aboveground growth}

Plant height and spread of the first three plants in each treatment were measured during the fifth week of the flowering stage. Plant height $(\mathrm{cm})$ was measured from the lid of the DWC unit to the top of the apical inflorescence, and plant spread $(\mathrm{cm})$ was measured at the widest point on the plant and then perpendicular to this measurement. Growth index (GI) was then calculated using the formula $\left(\mathrm{GI}=\right.$ (height $\mathrm{x}$ width $1 \mathrm{x}$ width $\left._{2}\right)$ / 300) (Caplan et al., 2017a). Plants were destructively harvested during the eighth week of flowering. To assess aboveground (including inflorescence) fresh weight (FW), plants were cut at substrate level and individually weighed on a digital balance.

\section{Root weight}

During harvest, roots from the first three replicates of each treatment were cut from around the outer surface of the mesh pot and air dried for several days and then oven-dried at $92^{\circ} \mathrm{C}$ for 72 hours and weighed (EG2200-2NM, KERN \& SOHN, Balingen, Germany) to obtain root dry weight (DW).

\section{Inflorescence yield}

Inflorescence material was trimmed of leaf tissue, removed from the stem, and then weighed to obtain inflorescence fresh weight (g/plant). To determine inflorescence dry weight (i.e., yield), $\sim 25 \mathrm{~g}$ samples of fresh inflorescence material from the first three plants in each treatment were weighed, dried at $70^{\circ} \mathrm{C}$ for 72 hours, and then re-weighed to obtain dry weight (DW). Yield was computed on a per-plant basis as the total inflorescence $\mathrm{FW} \times($ sample DW/sample FW). Cured 'whole-bud' cannabis inflorescence sold commercially normally contains 10 to $15 \%$ water. Therefore, the marketable yield can be calculated from inflorescence DW by factoring in the appropriate water content.

\section{Cannabinoid content}

Representative samples ( $\sim 50 \mathrm{~g})$ of fresh inflorescence from three plants per treatment were dried at $18{ }^{\circ} \mathrm{C}$ and $50 \%$ relative humidity until inflorescence material reached $\sim 10 \%$ moisture.

Composite sub-samples $(\sim 10 \mathrm{~g})$ of air-dried inflorescence material from the first three replicates in each treatment were vacuum-sealed and sent to Hexo Corp's in-house laboratory to determine cannabinoid concentration, including delta-9-tetrahydrocannabinol ( $\Delta^{9}$-THC), tetrahydrocannabinolic acid (THCA), cannabidiol (CBD), cannabidiolic acid (CBDA), cannabigerol (CBG), cannabigerolic acid (CBGA), cannabichromene (CBC), cannabinol (CBN), and delta-8-tetrahydrocannabinol $\left(\triangle^{8}\right.$-THC).

The cannabinoid analysis was conducted using ultra performance liquid chromatography (UPLC) separation. The composite sub-sample of dried cannabis was milled to a fine powder; from which1.0g was extracted with an Acetontrile $/ \mathrm{H}_{2} \mathrm{O}$ mixture with sonication and agitation for 20 
minutes at ambient temperature. A $1.5 \mathrm{~mL}$ aliquot was diluted and filtered into a HPLC vial and analysed as per 7020006509EN (Layton and Aubin, 2019).

\section{Statistical design and analysis}

RStudio software (RStudio Team, 2020) was used for data analysis. Normality and homoscedasticity of the data was assessed, and the data met these assumptions. The RStudio package 'rsm' (Lenth, 2009) was used to analyze inflorescence yield and to generate threedimensional and contour plots to represent the response surface. To improve precision of yield estimates, the average yield of the five replicates in each treatment was used. Two sets of three surface and contour plots were created, each while holding one of the nutrient concentrations fixed at its centre point. These surface and contour plots, along with canonical analysis, were then used to determine the optimal rate of all three factors. Correlation analysis of yield and vegetative parameters was performed using the RStudio software package 'ggplot2' (Wickham, 2016). To determine if there were differences in inflorescence cannabinoid content attributable to treatment, data from cannabinoid analysis was tested with a one-way ANOVA followed by Tukey's HSD post-hoc test.

\section{Statistical model}

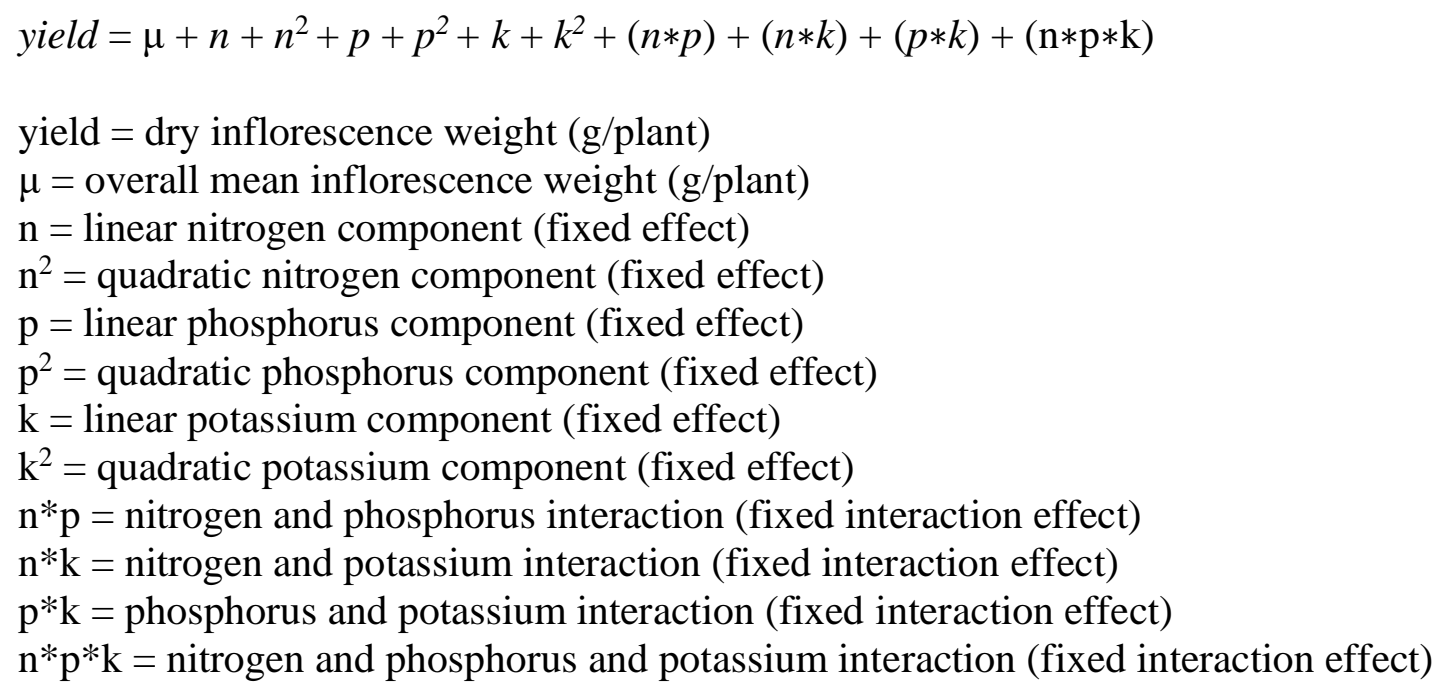

\section{Results}

\section{Inflorescence yield response}

Cannabis inflorescence yield responded to increasing $\mathrm{N}$ and $\mathrm{P}$ supply but did not respond to $\mathrm{K}$ within the tested range (Figures 2 and 3). Based on the surface response model, the highest average yield of $144 \mathrm{~g} /$ plant was achieved with $\mathrm{N}$ and $\mathrm{P}$ concentrations of $194 \mathrm{mg} \mathrm{L}^{-1}$ and $59 \mathrm{mg}$ $\mathrm{L}^{-1}$, respectively. Visual analysis of contour graphs (with a 5 gram resolution) show that yield responded to $\mathrm{N}$ best in the range of $160-230 \mathrm{mg} \mathrm{L}^{-1}$, and $\mathrm{P}$ in the range of $40-80 \mathrm{mg} \mathrm{L}^{-1}$ (Figure 2). 
Figure 2. Three-dimensional response surfaces for inflorescence yield (g/plant) at a range of nutrient solution $N, P$, and $K$ concentrations $\left(m L^{-1}\right)$ of Cannabis sativa grown in deep water culture $\left(P \leq 0.05, R^{2}=0.57\right)$. (A) Surface plot of $K v s$. $P$ at $N=180 \mathrm{mg} \mathrm{L}^{-1}(B)$ Surface plot of $K$ vs. $N$ at $P=60 \mathrm{mg} \mathrm{L}^{-1}(C)$ Surface plot of $P$ vs. $N$ at $K=200 \mathrm{mg} \mathrm{L}^{-1}$.
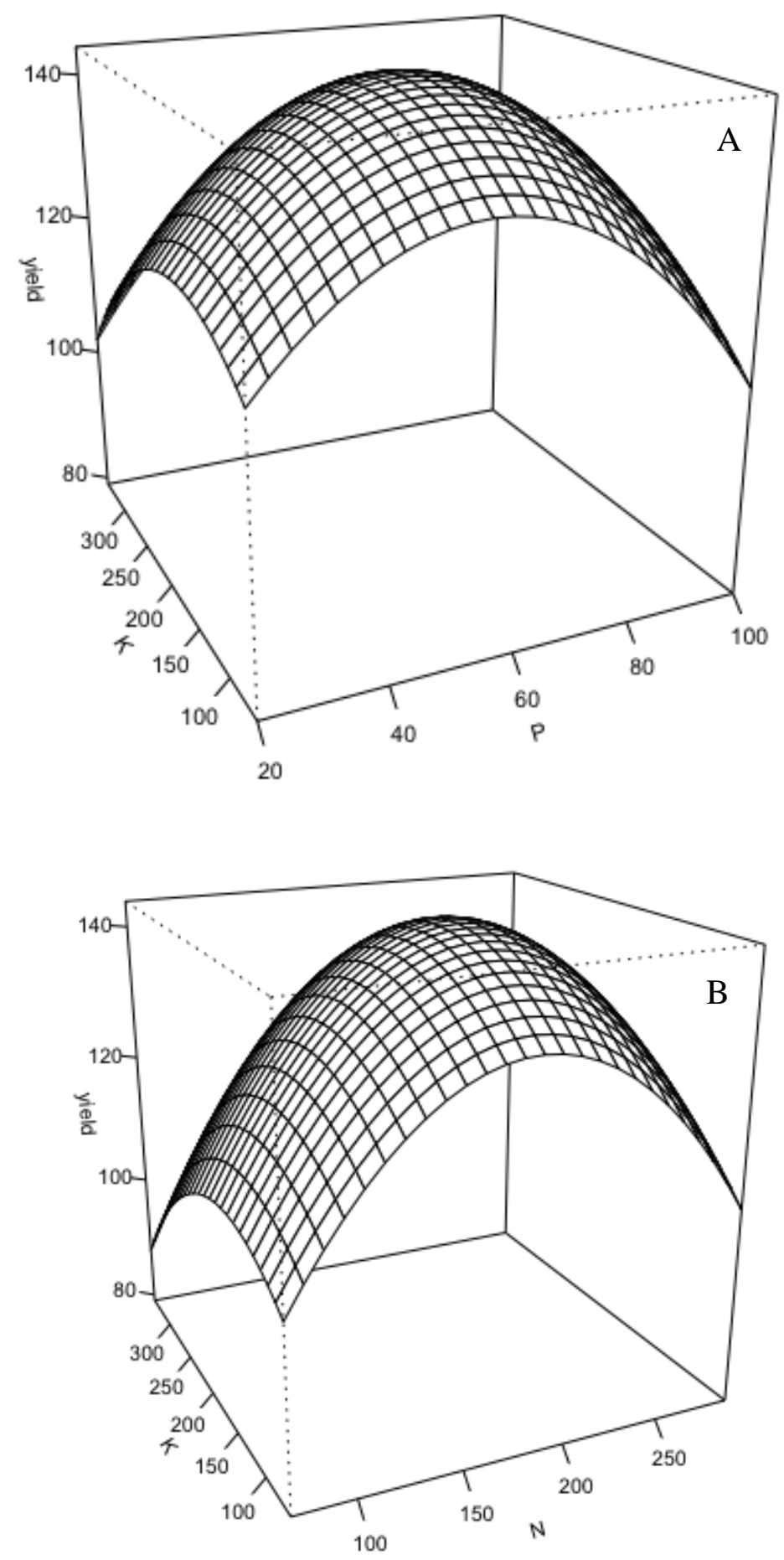


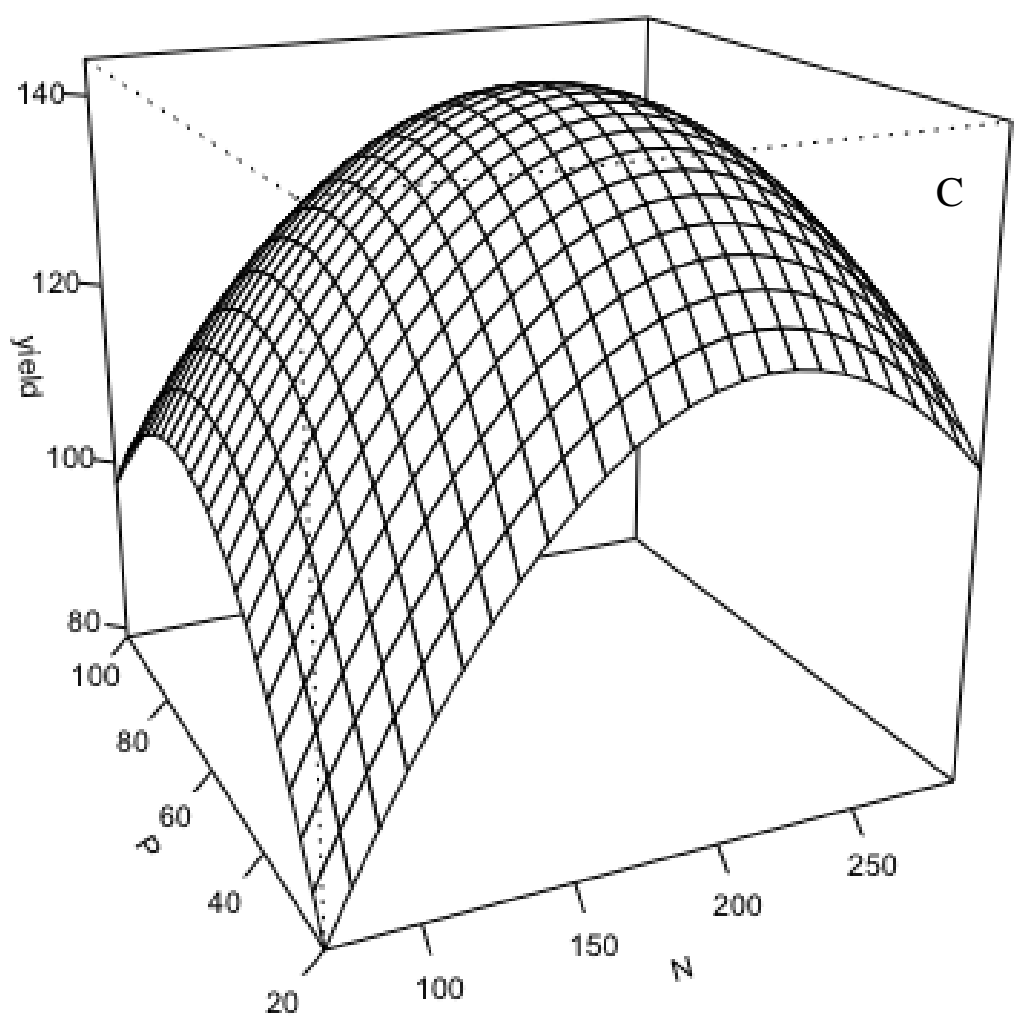

Figure 3. Contour plots showing the effect of nutrient solution $N, P$, and $K$ concentrations ( $m g L^{-}$ $\left.{ }^{1}\right)$ on inflorescence yield (g/plant) of Cannabis sativa grown in deep water culture $\left(P \leq 0.05, R^{2}\right.$ = 0.57). (A) Contour plot of $P$ vs. K at $N=180 \mathrm{mg} \mathrm{L}^{-1}(B)$ Contour plot of $N$ vs. $K$ at $P=60 \mathrm{mg}$ $L^{-1}(C)$ Contour plot of $N$ vs. $P$ at $K=200 \mathrm{mg} \mathrm{L}^{-1}$.

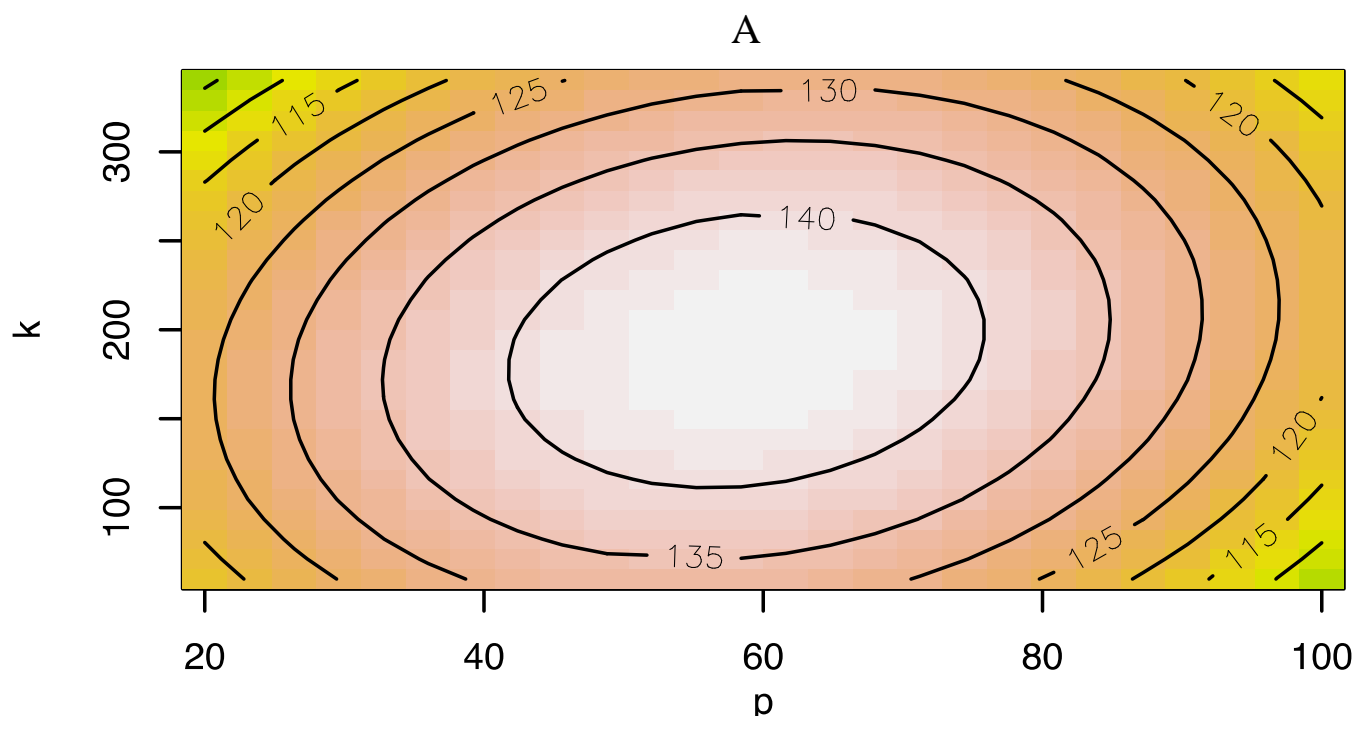



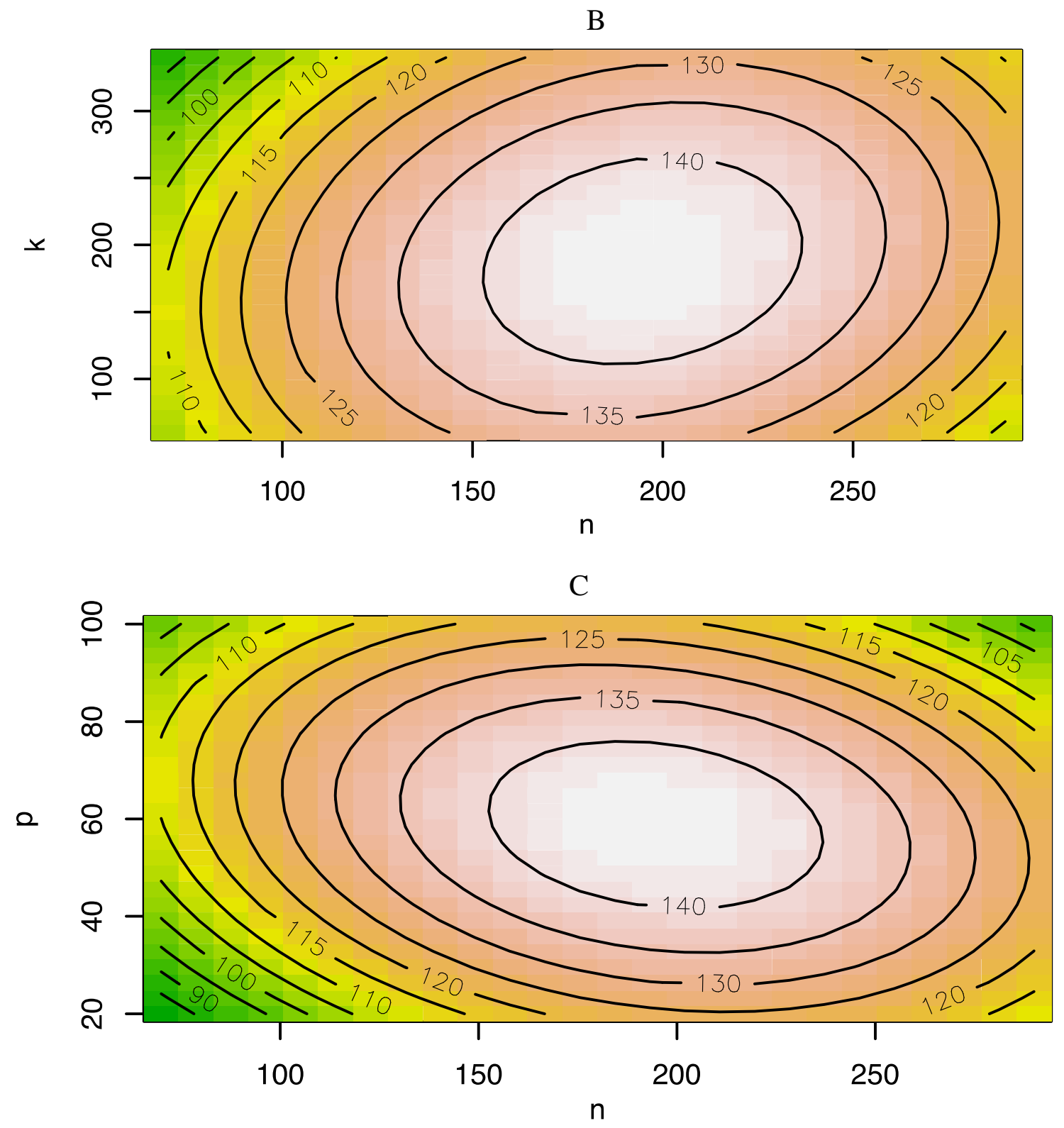

\section{Cannabinoid content}

There were no nutrient treatment effects on the inflorescence cannabinoid content. The average cannabinoid contents are listed in Table 4. In addition to those cannabinoids listed, the following were below the detection limits (i.e., $<0.5 \mathrm{mg} / \mathrm{g}$ ): $\mathrm{CBC}, \mathrm{CBD}, \mathrm{CBDA}, \mathrm{CBN}, \Delta^{8} \mathrm{THC}$. 
Table 4. Dry inflorescence cannabinoid contents of Cannabis sativa grown in the deep-water culture system with different NPK concentrations in the solution.

\begin{tabular}{cc}
\hline Cannabinoid & Concentration in inflorescence $\left(\mathrm{mg} \mathrm{g}^{-1}\right)^{\mathrm{b}}$ \\
\hline CBG & $0.86 \pm 0.01$ \\
CBGA & $3.9 \pm 0.08$ \\
THC & $4.4 \pm 0.09$ \\
THCA & $161 \pm 2.32$ \\
Total THC $^{\mathrm{a}}$ & $146 \pm 2.06$ \\
\hline
\end{tabular}

${ }^{a}$ Total THC $=[$ THC $]+0.877[$ THCA $]$

${ }^{b}$ Mean $\pm S E(n=60)$.

\section{Relationships between inflorescence yield and vegetative growth attributes}

No nutrient deficiency or toxicity symptoms were observed on any plants. Inflorescence yield was linearly and positively correlated with the measured vegetative growth attributes.

Inflorescence yield had significant correlations with aboveground plant fresh weight (Figure 4), plant growth index (Figure 5), and root dry weight (Figure 6).

Figure 4. Correlation between inflorescence yield ( $\mathrm{g} / \mathrm{plant}$ ) and aboveground plant fresh weight (g/plant) of Cannabis sativa $(r=0.98, P<0.001)$. Shaded area represents $95 \%$ confidence interval.

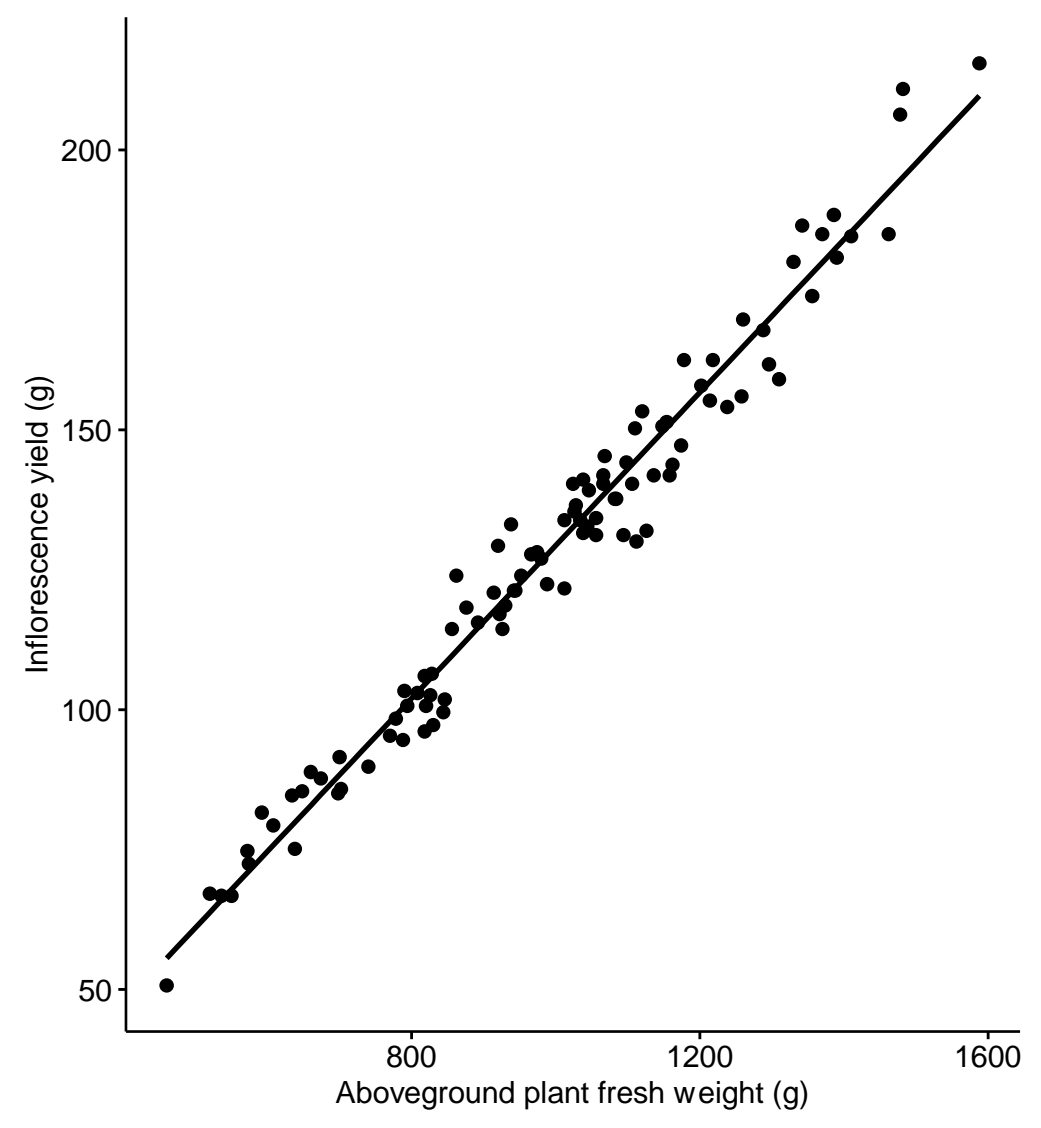


Figure 5. Correlation between inflorescence yield ( $\mathrm{g} / \mathrm{plant})$ and plant growth index of Cannabis sativa $(r=0.67, P<0.001)$. Shaded area represents $95 \%$ confidence interval.

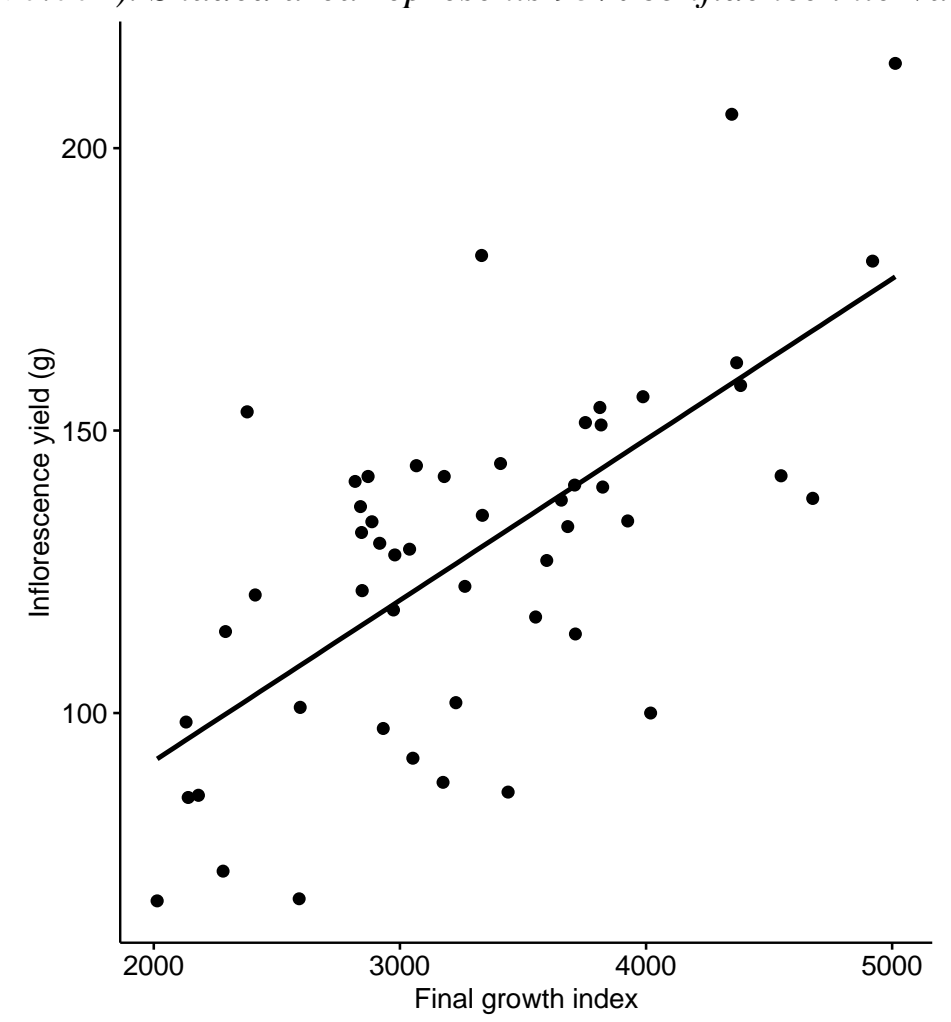

Figure 6. Correlation between inflorescence yield and root dry weight of Cannabis sativa $(r=$ $0.9, P<0.001)$. Shaded area represents $95 \%$ confidence interval.

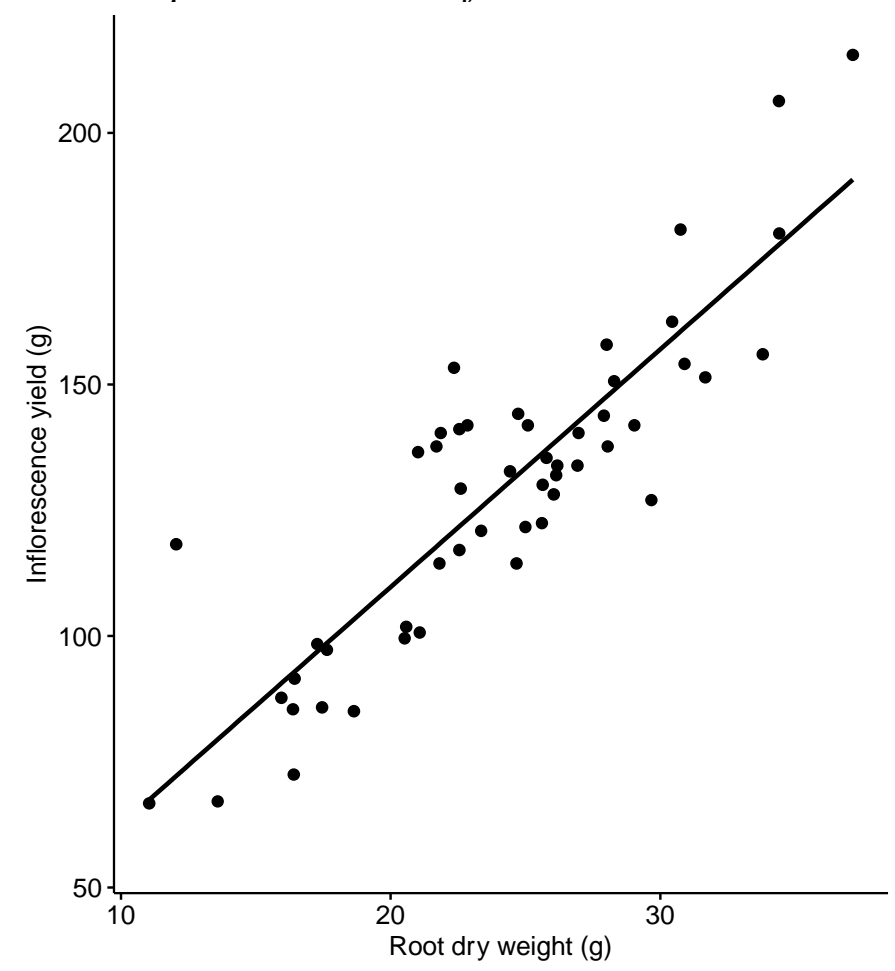




\section{Discussion}

The goal of this study was to determine the optimal concentration of N, P, and $\mathrm{K}$ in the nutrient solution for the flowering stage of soilless cannabis production using RSM. The optimal concentrations of nutrient solution $\mathrm{N}$ and $\mathrm{P}$ was predicted to be approximately $194 \mathrm{mg} \mathrm{L}^{-1} \mathrm{~N}, 59$ $\mathrm{mg} \mathrm{L}^{-1} \mathrm{P}$, respectively. Based on analysis of the response surface model, it was found $\mathrm{N}$ and $\mathrm{P}$ were the most important factors in predicting inflorescence yield. Inflorescence yield decreased markedly outside of the range of $160-240 \mathrm{mg} \mathrm{L}^{-1} \mathrm{~N}$, and $40-80 \mathrm{mg} \mathrm{L}^{-1} \mathrm{P}$. These findings suggest that drug-type cannabis responds well to nitrogen and phosphorus during the flowering stage. Inflorescence yield did not respond to nutrient solution $\mathrm{K}$ concentration within the tested range, indicating the $\mathrm{K}$ currently supplied (300-400 $\mathrm{mg} \mathrm{L}^{-1}$ ) by some commercial cultivators are likely too high.

Inflorescence yield had a strong positive correlation with a number of vegetative growth attributes. The strong correlation between inflorescence yield and plant growth index indicates that larger plant size can result in higher inflorescence yield. Nutrient supply, especially N, can determine cannabis plant size as $\mathrm{N}$ is an essential component of plant chlorophyll and ribulose1,5-bisphosphate carboxylase-oxygenase (Rubisco). Low levels of $\mathrm{N}$ can reduce plant photosynthetic capacity and limit plant growth (Saloner and Bernstein, 2020). For flowering drug-type cannabis in soilless culture, supply of 30 and $80 \mathrm{mg} \mathrm{L}^{-1} \mathrm{~N}$ restricted whole plant and inflorescence growth, but plants performed optimally with supply of 160-320 mg L $\mathrm{m}^{-1} \mathrm{~N}$ (Saloner and Bernstein, 2021). The optimal $\mathrm{N}$ supply (194 $\left.\mathrm{mg} \mathrm{L}^{-1}\right)$ found in our study is within their range, despite the two studies using two different growing methods and plants with different genetic backgrounds. For drug-type cannabis during the flowering stage in an organic-based soilless production system, the optimal $\mathrm{N}$ supply was slightly higher (212 to $261 \mathrm{mg} \mathrm{L}^{-1}$; Caplan et al., 2017a) than the optimal level found in the present study. A possible explanation for the higher optimal $\mathrm{N}$ supply in the organic fertilizer study is that $\mathrm{N}$ from organic-based fertilizers may not always be readily available, as the release of $\mathrm{N}$ from organic fertilizers depends on the speed and extent of the mineralization process (Hartz et al., 2010; Dion et al., 2020). Though it is unclear what source of organic nitrogen was used in their study, factoring in organic $\mathrm{N}$ availability of around 60\% would put our findings in line with those by Caplan et al. (2017a). Along with aboveground growth, root growth also contributes to overall plant size. We found that inflorescence yield had a strong positive correlation with root dry weight, supporting our conclusion that larger plants produce higher yields. The context of where plants spend their energy is important. For industrial hemp, increasing $\mathrm{N}$ supply increased plant growth, but this growth was partitioned more toward stem material rather than valuable inflorescence material (Campiglia et al., 2017). Further investigations of cannabis response to nitrogen should consider product quality, and the distribution of biomass to various plant organs to maximize inflorescence growth and quality.

While modeling of cannabis inflorescence yield response to $\mathrm{N}, \mathrm{P}$, and $\mathrm{K}$ with surface analysis accounts for interaction between nutrients, the surface response model demonstrated that $\mathrm{K}$, within the tested range of $60-340 \mathrm{mg} \mathrm{L}^{-1}$, had no effect on inflorescence yield. This lack of response may suggest that $60 \mathrm{mg} \mathrm{L}^{-1} \mathrm{~K}$ is not low enough to cause nutrient deficiency, and 340 $\mathrm{mg} \mathrm{L}^{-1} \mathrm{~K}$ is not high enough to cause toxicity. Moreover, cannabis responses to $\mathrm{K}$ may be cultivar specific. Plants of one cannabis cultivar supplied with $240 \mathrm{mg} \mathrm{L}^{-1} \mathrm{~K}$ had $25 \%$ reduced 
fresh shoot and root biomass by compared to those fed $175 \mathrm{mg} \mathrm{L}^{-1}$, while plants of another cultivar had up to $40 \%$ increased shoot and root biomass (Saloner et al., 2019). Plant height, number of nodes on the main stem, and stem diameter of these two cultivars remained similar, so this difference in biomass was caused by one cultivar becoming "bushier" than the other under high $\mathrm{K}$ supply. These difference in response to $\mathrm{K}$ supply may be due to differences in plant tissue (e.g., main stem vs side branch) sensitivity to K. Plant phenological stage (i.e., vegetative or flowering stage) may also be a factor in cannabis response to $\mathrm{K}$ supply. In a previous study of flowering aquaponic cannabis response to $\mathrm{K}$, inflorescence yield increased when plants were provided with $\mathrm{K}$ up to $150 \mathrm{mg} \mathrm{L}^{-1}$ (Yep and Zheng, 2020). Cultivar and plant phenological stage should be considered in future studies looking at cannabis response to nutrients, especially $\mathrm{K}$.

Many commercial cannabis cultivation operations currently use fertilizer formulations that contain very high levels of $\mathrm{P}$ (more than $200 \mathrm{mg} \mathrm{L}^{-1} \mathrm{P}$ in some cases). This practice is based on anecdotal evidence that $\mathrm{P}$ enhances inflorescence production. These concentrations are much higher than the optimal rate of $60 \mathrm{mg} \mathrm{L}^{-1} \mathrm{P}$ found in our study, and at the higher range could cause reduction of both plant growth and inflorescence yield. In addition to reducing plant growth and yield, excessive supply of nutrients is a potential source of environmental pollution. Though, cannabis does appear to have the ability to store and mobilize certain amount of $\mathrm{P}$ when required. When provided with $\mathrm{P}$ higher than $30 \mathrm{mg} \mathrm{L}^{-1}$ in the vegetative stage, cannabis sequestered excess $\mathrm{P}$ in root tissue to prevent excess accumulation in the shoots (Shiponi and Bernstein, 2021). A greater understanding of what cannabis $P$ requirements are, and whether there is any truth to the practice of supplying high concentrations of $\mathrm{P}$, should be a priority for making cannabis production more sustainable. However, based on our data it appears that the levels of $\mathrm{P}$ found in many cannabis specific commercial fertilizers are far higher than needed and could lead to negative environmental impacts.

While the cannabinoid concentrations in the floral tissues in our study did not respond to nutrient solution NPK concentrations, other studies indicate that plant mineral nutrition can affect production of secondary metabolites in cannabis (Caplan et al., 2017a; Saloner and Bernstein, 2021). There appears to be an inverse relationship between cannabis yield and potency, with cannabinoid concentrations decreasing as plant inflorescence yield increases. Inflorescence from plants supplied with $160 \mathrm{mg} \mathrm{L}^{-1} \mathrm{~N}$ had approximately $30 \%$ and $20 \%$ lower concentrations of THCA and CBDA than plants supplied with $30 \mathrm{mg} \mathrm{L}^{-1} \mathrm{~N}$ (Saloner and Bernstein, 2021). But while nutrient stress and deficiency may enhance inflorescence cannabinoid content, this method is not ideal for optimizing overall plant productivity as plants supplied with $160 \mathrm{mg} \mathrm{L}^{-1} \mathrm{~N}$ yielded twice that of those supplied with $30 \mathrm{mg} \mathrm{L}^{-1} \mathrm{~N}$. Cannabis grown in two organic growing media with different organic fertilizer rates (i.e., 57, 113, 170, 226 and $283 \mathrm{mg} \mathrm{L}^{-1} \mathrm{~N}$ ) had negative linear relationships between the concentrations of inflorescence THCA and CBGA and the fertilizer application rate for some of the treatment combinations (i.e., growing media and fertilizer rate) (Caplan et al., 2017a). However, for majority of the treatment combinations, fertilizer rates from $57-226 \mathrm{mg} \mathrm{L}^{-1} \mathrm{~N}$ did not have any effects on THCA or CBGA concentrations; and the cannabinoid concentrations only dropped when the fertilizer rate increased to the highest level of $283 \mathrm{mg} \mathrm{L}^{-1} \mathrm{~N}$. The context of yield is again important when analyzing differences in cannabinoid content as THCA concentrations dropped by $\sim 20 \%$ in the highest fertilizer rate, but inflorescence yield almost doubled vs. lowest fertilizer rate. As noted by Bernstein et al. (2019), an understanding of how nutrient supply influences cannabinoid 
concentrations would be an important step toward controlling and standardizing the cannabinoid contents of medical cannabis. Cannabinoid concentrations are also important to recreational consumers, who rank THC and CBD concentrations among the most important factors when making purchasing decisions (Zhu et al., 2020). Given that cannabinoids are the compounds that make cannabis so uniquely valuable, more work needs to be done to investigate the effect of mineral nutrition on cannabis yield, and the relationship between yield and potency.

The use of central-composite design allows experimenters to account for potential interactions between the different nutrients. This is important as nutrient interactions have been shown to affect plant nutrient uptake (Fageria, 2001; Rietra et al., 2017). A recent study found that high K supply decreased concentrations of $\mathrm{Ca}$ and $\mathrm{Mg}$ in cannabis leaf tissue, indicating antagonistic relationships between these positively charged ions (Saloner et al., 2019). An understanding of how combinations of nutrients at different concentrations affect crop growth and yield is important for the development of recommendations for the commercial cannabis industry. Had the same number of nutrients and nutrient levels as were included in this study been investigated with a traditional full-factorial design, many more nutrient solution treatment groups would have been required, compared to the number of treatment groups used in this study. The difference in number of treatment groups needed can be more pronounced as more factors (i.e., $\mathrm{Ca}, \mathrm{Mg}$ ) are included. Considering the high cost of cannabis and growing space in controlled environments, the response surface approach allowed us to complete this study where another experimental design may have been prohibitive.

No matter the experimental design used, an inherent problem in nutrient solution experiments is that nutrients cannot be added individually but must be added as a compound containing both anions and cations. Further, the ionic balance constraint requires the sum of the charges of cations and anions in solution to be equal (De Rijck and Schrevens, 1999b). The implication for formulating experimental treatment solutions is that it is practically impossible to change the level of one nutrient while keeping concentrations of all other nutrients the same. In this study, we focused on N, P, and K concentrations while attempting to keep all other nutrients at reasonable levels using commonly available horticultural fertilizer compounds. For example, potassium nitrate and calcium nitrate usually contribute the bulk of nitrogen, potassium, and calcium in horticultural nutrient solutions (Resh, 2012). Formulating a high N, low K nutrient solution with these fertilizers results in higher levels of $\mathrm{Ca}$ than other nutrient solution treatments. Likewise, a low N, high K nutrient solution necessitates an additional source of $\mathrm{K}$ such as $\mathrm{KCl}$, which would increase solution $\mathrm{Cl}$ concentration. Higher concentrations of nutrients such as $\mathrm{Ca}$ and $\mathrm{Cl}$ bring the potential for nutrient interactions which may affect experimental results. The lack of response to $\mathrm{K}$ in the range of $60-340 \mathrm{mg} \mathrm{L}^{-1}$ observed in our trial may be partially due to competition for uptake from $\mathrm{Ca}$. Regarding experimental $\mathrm{Cl}$ levels, hydroponic cannabis has been shown to tolerate rates of $180 \mathrm{mg} \mathrm{L}^{-1} \mathrm{Cl}$ with no impact on yield or potency (Yep et al., 2020a) so it is unlikely $\mathrm{Cl}$ levels limited plant growth in this trial. Though less than ideal in an experimental setting, there is no perfect solution for the problem of keeping all nutrient concentrations the same when formulating treatment solutions.

While this trial determined the theoretical optimum levels of $\mathrm{N}$ and $\mathrm{P}$ for the DWC growing method, these levels may not be definitive for all production methods. Our trial was conducted in solution culture with weekly nutrient solution changes, and the EC and $\mathrm{pH}$ dynamics of our 
DWC units are likely different than other growing methods, meaning that plant nutrient availability and overall salinity of the nutrient solution would also likely be considerably different. Many commercial cannabis operations utilize substrate-based soilless cultivation systems, such as coir in containers, that may offer more nutrient and $\mathrm{pH}$ buffering capacity (Zheng, 2020). Having said that, our trial does represent or closely resemble some common soilless production practices, such as growing cannabis in rockwool, in the current cannabis production industry (Zheng, 2021). Another limitation of our study was that we only used a single cannabis cultivar. Similar experiments should be performed on different cultivars, with disparate growth habits and cannabinoid compositions to investigate how individual cultivars may respond to NPK treatment levels. Additionally, this study only looked at inflorescence yield and cannabinoid composition and did not evaluate the impact of NPK on inflorescence terpene content or organoleptic properties.

Drug-type cannabis is still a relatively new crop in the legal setting, especially for large-scale commercial production, and many aspects of its cultivation are relatively unknown. We found that response surface methodology was a suitable experimental approach for investigation of cannabis responses to NPK, and that modeling of yield response to these nutrients aided us in achieving our experimental objective. Based on the results of this study, we recommend providing plants with a nutrient solution containing $\mathrm{N}$ and $\mathrm{P}$ at approximately 194 and $59 \mathrm{mg} \mathrm{L}^{-1}$, respectively, to achieve maximal inflorescence yield. Future studies should investigate the inflorescence yield and vegetative growth response of genetically diverse cultivars to macronutrients and include more quality parameters to ensure that plant yields do not compromise product quality. Improving our understanding of cannabis responses to mineral nutrients is an essential step towards the effective and sustainable cultivation of this high-value horticultural crop.

\section{Acknowledgements}

We thank the Ontario Centres of Excellence and HEXO Co. for their financial support. This study would not have been possible without with support from Steve Dinka, Scott Golem, Liz Foley and the other growing facility staff at HEXO Co. We thank David Llewellyn for his technical on-site research support, aid in data collection, resourcefulness in provisioning materials, and his informative discussions. We thank Simon Bourque for performing the laboratory cannabinoid analysis. We also thank Master Plant Prod. Inc for their support and providing the straight fertilizer compounds used in this study. In addition, we thank Bluelab Corporation for providing $\mathrm{pH} / \mathrm{EC}$ meter parts and calibration solution for this trial.

\section{References}

Beerling, E. A. M., Blok, C., van der Maas, A. A., and van Os, E. A. (2014). Closing the water and nutrient cycles in soilless cultivation systems. Acta Hortic., 1034, 49-55. https://doi.org/10.17660/ActaHortic.2014.1034.4.

Bernstein, N., Gorelick, J., Zerahia, R., and Koch, S. (2019). Impact of N, P, K, and humic acid supplementation on the chemical profile of medical cannabis (Cannabis sativa L.). Front. Plant. Sci. 10, 736-736. https://doi.org/10.3389/fpls.2019.00736. 
Campiglia, E., Radicetti, E., and Mancinelli, R. (2017). Plant density and nitrogen fertilization affect agronomic performance of industrial hemp (Cannabis sativa L.) in Mediterranean environment. Ind. Crop. Prod. 100, 246-254. https://doi.org/10.1016/j.indcrop.2017.02.022.

Caplan, D., Dixon, M., and Zheng, Y. (2017a). Optimal rate of organic fertilizer during the flowering stage for cannabis grown in two coir-based substrates. HortScience 52, 17961803. https://doi.org/10.21273/hortsci12401-17.

Caplan, D., Dixon, M., and Zheng, Y. (2017b). Optimal rate of organic fertilizer during the vegetative-stage for cannabis grown in two coir-based substrates. HortScience 52, 13071312. https://doi.org/10.21273/hortsci11903-17.

De Rijck, G., and Schrevens, E. (1998). Multifactorial optimisation of the nutrient solution for hydroponically grown chicory plants. Sci. Hortic. 76, 149-159.

https://doi.org/10.1016/S0304-4238(98)00126-5.

De Rijck, G., and Schrevens, E. (1999a). Application of mixture theory for the optimisation of the composition of nutrient solutions for hydroponic cropping: practical use. Acta Hortic. 481, 205-212. https://doi.org/10.17660/ActaHortic.1999.481.21.

De Rijck, G., and Schrevens, E. (1999b). Chemical feasibility region for nutrient solutions in hydroponic plant nutrition. J. Plant Nutr. 22, 259-268.

https://doi.org/10.1080/01904169909365624.

Dion, P.-P., Jeanne, T., Thériault, M., Hogue, R., Pepin, S., and Dorais, M. (2020). Nitrogen release from five organic fertilizers commonly used in greenhouse organic horticulture with contrasting effects on bacterial communities. Can. J. Soil. Sci. 100, 120-135. https://doi.org/10.1139/cjss-2019-0056.

Fageria, V. D. (2001). Nutrient interactions in crop plants. J. Plant Nutr. 24, 1269-1290. https://doi.org/10.1081/pln-100106981.

Hartz, T. K., Smith, R., and Gaskell, M. (2010). Nitrogen availability from liquid organic fertilizers. HortTechnology 20, 169-172. https://doi.org/10.21273/horttech.20.1.169.

Layton, C., and Aubin, A. J. (2019) UPLC Separation for the analysis of cannabinoid content in cannabis flowers and extracts. Available at: https://www.waters.com/webassets/cms/library/docs/720006509en.pdf

Lenth, R. V. (2009). Response-surface methods in R, using rsm. J. Stat. Softw. 32, 1-17.

Myers, R. H., Montgomery, D. C., and Anderson-Cook, C. M. (2016). Response Surface Methodology: Process and Product Optimization using Designed Experiments. 4th ed. Hoboken, New Jersey: Wiley. 
Ontario Ministry of Agriculture Food and Rural Affairs (2019). Nutrient ManagementGreenhouse Nutrient Feedwater Regulation. Available at: http://www.omafra.gov.on.ca/english/nm/regs/gnfpro/gnfreg.htm.

Resh, H. M. (2012). Hydroponic food production: a definitive guidebook for the advanced home gardener and the commercial hydroponic grower. 7th ed. Boca Raton, FL: CRC Press, Taylor \& Francis Group.

Rietra, R. P. J. J., Heinen, M., Dimkpa, C. O., and Bindraban, P. S. (2017). Effects of nutrient antagonism and synergism on yield and fertilizer use efficiency. Commun. Soil. Sci. Plant Anal. 48, 1895-1920. https://doi.org/10.1080/00103624.2017.1407429.

RStudio Team (2020). RStudio: Integrated Development Environment for R. Boston, MA: RStudio, PBC Available at: http://www.rstudio.com/.

Saloner, A., and Bernstein, N. (2020). Response of medical cannabis (Cannabis sativa L.) to nitrogen supply under long photoperiod. Front. Plant Sci. 11, 572293. https://doi.org/10.3389/fpls.2020.572293.

Saloner, A., and Bernstein, N. (2021). Nitrogen supply affects cannabinoid and terpenoid profile in medical cannabis (Cannabis sativa L.). Ind. Crop. Prod. 167, 113516. https://doi.org/10.1016/j.indcrop.2021.113516.

Saloner, A., Sacks, M. M., and Bernstein, N. (2019). Response of medical cannabis (Cannabis sativa L.) genotypes to K supply under long photoperiod. Front. Plant Sci. 10, 1369. https://doi.org/10.3389/fpls.2019.01369.

Schindler, D. W., Carpenter, S. R., Chapra, S. C., Hecky, R. E., and Orihel, D. M. (2016). Reducing phosphorus to curb lake eutrophication is a success. Environ. Sci. Technol. 50, 8923-8929. https://doi.org/10.1021/acs.est.6b02204.

Shiponi, S., and Bernstein, N. (2021). Response of medical cannabis (Cannabis sativa L.) genotypes to $\mathrm{P}$ supply under long photoperiod: Functional phenotyping and the ionome. Ind. Crop. Prod. 161, 113154. https://doi.org/10.1016/j.indcrop.2020.113154.

Wickham, H. (2016). ggplot2: Elegant Graphics for Data Analysis. Springer-Verlag New York Available at: https://ggplot2.tidyverse.org.

Yep, B., Gale, N. V., and Zheng, Y. (2020a). Aquaponic and hydroponic solutions modulate $\mathrm{NaCl}$-induced stress in drug-type Cannabis sativa L. Front. Plant Sci. 11, 1169. https://doi.org/10.3389/fpls.2020.01169.

Yep, B., Gale, N. V., and Zheng, Y. (2020b). Comparing hydroponic and aquaponic rootzones on the growth of two drug-type Cannabis sativa L. cultivars during the flowering stage. Ind. Crop. Prod. 157, 112881. https://doi.org/10.1016/j.indcrop.2020.112881. 
Yep, B., and Zheng, Y. (2020). Potassium and micronutrients fertilizer addition in aquaponic solution for drug-type Cannabis sativa L. cultivation. Can. J. Plant Sci. 101, 341-352. https://doi.org/10.1139/cjps-2020-0107.

Zheng, Y. (2018). Current nutrient management practices and technologies used in North American greenhouse and nursery industries. Acta Hortic. 1227, 435-442. https://doi.org/10.17660/ActaHortic.2018.1227.54.

Zheng, Y. (2020). Integrated rootzone management for successful soilless culture. Acta Hortic. 1273, 1-8. https://doi.org/10.17660/ActaHortic.2020.1273.1.

Zheng, Y. (2021). Soilless production of drug-type Cannabis sativa. Acta Hortic. 1305, 376382. https://doi.org/10.17660/ActaHortic.2021.1305.49.

Zhu, B., Guo, H., Cao, Y., An, R., and Shi, Y. (2020). Perceived importance of factors in cannabis purchase decisions: a best-worst scaling experiment. Int. J. Drug Policy, 102793. https://doi.org/10.1016/j.drugpo.2020.102793. 